\title{
HUBUNGAN POLA ASUH ORANGTUA DENGAN KESIAPAN TOILET TRAINING PADA ANAK USIA TODDLER
}

\author{
Aidatul Fitri Mail ${ }^{1}$, Romdzati²* \\ ${ }^{1}$ Universitas Muhammadiyah Yogyakarta \\ 2Program Studi Ilmu Keperawatan, Universitas Muhammadiyah Yogyakarta \\ *Email: romdzati@gmail.com
}

\begin{abstract}
ABSTRAK
Latar Belakang: Salah satu tugas perkembangan anak pada usia toddler adalah toilet training. Toilet training adalah suatu proses pengajaran kepada anak untuk mengontrol buang air kecil dan buang air besar secara benar dan teratur. Kesiapan toilet training pada anak usia toddler tidak hanya dipengaruhi oleh kesiapan fisik, psikologis, mental, dan orang tua tetapi bisa juga dipengaruhi oleh pola asuh orang tua yang diterapkan ke anak. Pola asuh orang tua ada tiga macam diantaranya otoriter, permisif, dan demokratis.

Tujuan: Penelitian ini bertujuan untuk mengetahui hubungan pola asuh orang tua dengan kesiapan toilet training pada anak usia toddler Yogyakarta.

Metode: Penelitian ini merupakan penelitian non-eksperimen dengan desain correlational melalui pendekatan cross-sectional. Sampel dalam penelitian ini sebanyak 44 responden dengan pengambilan sampel melalui teknik purposive sampling. Uji statistic menggunakan chi-square dengan $\mathrm{a}=0,05$.

Hasil: Penelitian ini menunjukkan sebagian besar orang tua menerapkan pola asuh demokratis yaitu sebanyak 30 responden $(68,2 \%)$ dengan kesiapan toilet training sebanyak 22 responden $(73,3 \%)$. Korelasi menggunakan uji chi-square didapatkan hasil nilai $\mathrm{p}=0,040$.

Kesimpulan: Berdasarkan analisis data diperoleh nilai signifikan $\mathrm{p}=0,040<0,05$ yang berarti ada hubungan pola asuh orang tua dengan kesiapan toilet training pada anak usia toddler.
\end{abstract}

Kata kunci: Pola asuh, Kesiapan toilet training, Anak usia toddler.

\section{ABSTRACT}

Background: One of child development taskduring toddler age is toilet training. Toilet training is a process of teaching the child to control urination and defecation properly and regularly. Preparedness of toilet training for toddper is not only influenced by physical, psychological, mental, and parental readiness but may also be influenced by parenting style.

Objective: This study aims to determine the relationship between parenting and toilet training readiness among toddler Yogyakarta.

Method: This research is a non-experimental research with correlational design through crosssectional approach. Purposive sampling was used to collect 44 respondents. The statistical test used chi-square with a $=0.05$.

Results: The result showed that most of parents(68.2\%) applied democratic parenting style, meanwhile chi-square test obtained that $\mathrm{p}$ value $=0.040$.

Conclusion: Based on the data analysis, the significant value $\mathrm{p}=0.040<0.05$ which means there was a relationship between parenting and toilet training readinessamong toddler.

Keywords: Parenting, Toilet Training Readiness, Toddler 


\section{PENDAHULUAN}

Pertumbuhan dan perkembangan anak usia toddler sering disebut golden age sehingga anak dengan cepat dapat menerima informasi atau stimulus dari luar. ${ }^{1}$ Anak usia toddler berkisar antara 12-36 bulan yang ditandai dengan salah satu tugas perkembangannya yaitu toilet training. ${ }^{2}$

Toilet training adalah usaha orang tua untuk mengajarkan dan melatih anak dalam buang air kecil dan buang air besar secara teratur dan benar. ${ }^{3}$ Kemampuan anak untuk mengontrol buang air kecil dan buang air besar bergantung pada kematangan otot dan motivasi yang

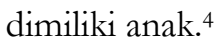

Kesiapan toilet training dipengaruhi oleh beberapa faktor diantarannya kesiapan fisik, psikologis, mental, dan kesiapan orang tua. ${ }^{5}$ Selain itu, faktor-faktor yang dapat mempengaruhi kesiapan toilet training diantarannya usia anak, jenis kelamin, dan pola asuh orang tua. Pola asuh orang tua berkaitan dengan orang tua dapat memberikan kasih sayang, memperhatikan, serta menilai tingkat perkembangan anak sesuai dengan usianya. ${ }^{6}$

Berdasarkan studi pendahuluan yang telah dilakukan oleh peneliti pada tanggal 8 oktober 2017 di Posyandu Balita Dusun Kalirandu dari 10 responden terdapat 6 orang tua memiliki anak sudah tidak mengompol, bisa buka celana sendiri, dan memberitahu ibu ketika ingin buang air. Sedangkan, 4 orang tua masih memiliki anak yang masih mengompol, anak tidak bisa buka celana sendiri, dan orang tua yang tidak mengganti popok yang sudah basah sampai anak menangis.

Berdasarkan latar belakang diatas peneliti tertarik untuk melakukan penelitian apakah ada hubungan pola asuh orang tua dengan kesiapan toilet training pada anak usia toddler di Kalirandu Bangunjiwo Kasihan Bantul Yogyakarta.

\section{METODE PENELITIAN}

Penelitian ini merupakan penelitian noneksperimental dengan desain correlation melalui pendekatan cross-sectional. Penelitian ini menggunakan kuesioner sebagai alat instrumen dalam pengumpulan data. Kuesioner terdiri dari 30 item pernyataan pola asuh orang tua dan 20 item pertanyaan kesiapan toilet training. Populasi pada penelitian ini yaitu seluruh orang tua yang memiliki anak usia toddler sebanyak 44 responden. Sampel pada penelitian ini menggunakan teknik purposive sampling dimana hanya mengambil anak yang berusia 12-36 bulan sebanyak 44 responden. Penelitian ini dilakukan di Posyandu Balita Teratai 1 Kalirandu Bangunjiwo Kasihan Bantul Yogyakarta.

Analisis univariat pada penelitian ini digunakan untuk mengetahui gambaran dari karakteristik demografi orang tua dan anak, pola asuh orang tua, dan kesiapan toilet training. Sedangkan, analisis bivariate pada penelitian ini menggunakan uji chi square untuk mengetahui apakah ada hubungan pola asuh orang tua

Vol. 1 No.5 Agustus 2018 
dengan kesiapan toilet training pada anak usia toddler di Kalirandu Bangunjiwo Kasihan Bantul Yogyakarta.

\section{HASIL PENELITIAN}

\section{Analisis Univariat}

Tabel. 1 Data demografi anak di Dusun Kalirandu Bangunjiwo Kasihan Bantul Yogyakarta pada bulan Januari 2018

\begin{tabular}{lcc}
\hline Karakteristik & Frekuensi & $\begin{array}{l}\text { Persentase } \\
(\mathbf{\%})\end{array}$ \\
\hline Jenis Kelamin & & \\
Laki-laki & 30 & 68,2 \\
Perempuan & 14 & 31,8 \\
Usia & & \\
1-2 tahun & 23 & 52,3 \\
2-3 tahun & 21 & 47,7 \\
\hline
\end{tabular}

Tabel di atas menunjukkan sebagian besar anak berusia 1-2 tahun, jenis kelamin laki-laki.

Tabel. 2 Data demografi orang tua di Dusun Kalirandu Bangunjiwo Kasihan Bantul Yogyakarta pada bulan Januari 2018

\begin{tabular}{lcr}
\hline Karakteristik & Frekuensi & $\begin{array}{l}\text { Persent } \\
(\mathbf{\%})\end{array}$ \\
\hline Jenis Kelamin & & \\
Laki-laki & 1 & 2,3 \\
Perempuan & 43 & 97,7 \\
Usia & & \\
20-40 tahun & 36 & 81,8 \\
41-60 tahun & 8 & 18,2 \\
>60 & 0 & 0 \\
Pekerjaan & & \\
IRT & 25 & 56,8 \\
Buruh & 10 & 22,7 \\
Wiraswasta & 7 & 15,9 \\
PNS & 2 & 4,5 \\
Pendidikan & & \\
Terakhir & & \\
SD & 3 & 6,8 \\
SMP & 10 & 22,7 \\
SMA & 21 & 47,7 \\
PT & 10 & 22,7
\end{tabular}

\section{Penghasilan}

$<$ Rp.600.000

Rp.600.000-

Rp.2.000.000

Rp.2.000.000-

Rp.5.000.000

$>$ Rp. 5.000 .000

15

21

34,1

47,4

$8 \quad 18,2$

0

Berdasarkan tabel di atas menunjukkan sebagian besar berjenis kelamin perempuan, usia antara 20-40 tahun, pendidikan terakhir SMA, ibu Rumah Tangga, dan penghasilan Rp600.000-Rp.2.000.000.

Tabel.3 Distribusi frekuensi pola asuh di Dusun Kalirandu Bangunjiwo Kasihan Bantul Yogyakarta pada bulan Januari 2018

\begin{tabular}{lcc}
\hline $\begin{array}{l}\text { Pola asuh } \\
\text { orang tua }\end{array}$ & Frekuensi & $\begin{array}{l}\text { Persentase } \\
(\mathbf{\%})\end{array}$ \\
\hline Otoriter & 14 & 31,8 \\
Permisif & 0 & 0 \\
Demokratis & 30 & 68,2 \\
\hline
\end{tabular}

Berdasarkan tabel di atas mayoritas pola asuh orang tua yang diperoleh dalam penelitian ini adalah pola asuh demokratis.

Tabel. 4 Distribusi frekuensi kesiapan toilet training di Dusun Kalirandu Bangunjiwo Kasihan Bantul Yogyakarta pada bulan Januari 2018

\begin{tabular}{lcc}
\hline $\begin{array}{l}\text { Kesiapan } \\
\text { toilet } \\
\text { training }\end{array}$ & Frekuensi & $\begin{array}{l}\text { Persentase } \\
\text { (\%) }\end{array}$ \\
\hline Tidak baik & 0 & 0 \\
Kurang baik & 0 & 0 \\
Cukup & 17 & 38,6 \\
Baik & 27 & 61,4 \\
\hline
\end{tabular}

Berdasarkan tabel di atas sebagian besar anak memiliki kesiapan toilet training dengan kategori baik. 


\section{Analisis Bivariat}

Tabel. 5 Hubungan pola asuh orang tua dengan kesiapan toilet training di Dusun Kalirandu Bangunjiwo Kasihan Bantul Yogyakarta pada bulan Januari 2018

\begin{tabular}{lccc}
\hline \multirow{2}{*}{$\begin{array}{c}\text { Pola } \\
\text { asuh }\end{array}$} & \multicolumn{2}{c}{$\begin{array}{c}\text { Kesiapan toilet } \\
\text { training }\end{array}$} & $\begin{array}{l}\text { Signifikan } \\
\text { si }\end{array}$ \\
\cline { 2 - 3 } & Cukup & Baik & \\
\hline Otoriter & $9(64,3 \%)$ & $\begin{array}{c}5(35,7 \\
0\end{array}$ & \\
& & $0,0)$ & \\
Permisif & $0(0 \%)$ & $0(0 \%)$ & \\
$\begin{array}{l}\text { Demokrat } \\
\text { is }\end{array}$ & $8(26,7 \%)$ & $\begin{array}{c}22 \\
(73,3 \%)\end{array}$ & \\
\hline
\end{tabular}

Berdasarkan tabel di atas, hasil analisa data dengan uji Chi-square untuk mengetahui hubungan pola asuh orang tua dengan kesiapan toilet training pada anak usia 1-3 tahun diperoleh nilai $p=0,024$. Dengan demikian, nilai $p<0,05$ maka dapat diambil kesimpulan ada hubungan antara pola asuh orang tua dengan kesiapan toilet training pada anak usia 1-3 tahun di Dusun Kalirandu Bangunjiwo Kasihan Bantul Yogyakarta.

\section{PEMBAHASAN}

\section{Analisis Univariat}

a. Gambaran data demografi orang tua orang tua di Dusun Kalirandu

Bangunjiwo Kasihan Bantul
Yogyakarta

Usia orang tua dapat mempengaruhi perkembangan anak karena sesuai dengan teori semakin cukup usia seseorang maka tingkat kematangan untuk menjadi orang tua lebih baik dan semakin matang, sehingga pemikiran dan pengetahuan terkait informasi yang diperoleh akan semakin luas .7 Pasangan orang tua dengan usia yang lebih tua cenderung menggunakan pola asuh bersifat otoriter dengan cara orang tua lebih dominan dalam mengambil keputusan karena mereka menganggap sangat berpengalaman dalam memberikan pengasuhan dan pendidikan kepada anak-anaknya. ${ }^{8}$

jenis kelamin orang tua mempengaruhi pola asuh pada anak dalam mengambil tindakan saat melakukan pengasuhan. Orang tua lakilaki saat mengasuh dan mendidik anak cenderung menghasilkan karakteristik anak yang kurang baik dan tidak patuh terhadap orang tua, sedangkan orang tua perempuan yang mengasuh anak mereka lebih bersikap lemah lembut dan tidak kasar sehingga menghasilkan karakteristik anak yang baik dan apabila pola asuh yang diterapkan benar maka anak tersebut akan menjadi baik dan lebih mandiri. ${ }^{9}$

Menurut salah satu penelitian, ${ }^{10}$ pengetahuan yang diperoleh dari pendidikan, di mana semakin tinggi pendidikan seseorang maka dapat memberikan pengetahuan lebih sehingga mereka lebih paham dengan 
materi atau strategi serta mampu dalam menerapkan apa yang diketahui. Pengetahuan orang tua akan meningkatkan pemahaman orang tua dalam mengasuh anak juga akan semakin baik.

Orang tua yang kesehariannya hanya sebagai ibu rumah tangga maka akan lebih fokus pada pengasuhan anak dan dapat menilai perkembangan anak dengan baik . ${ }^{11}$ Status pekerjaan orang tua dapat berpengaruh terhadap kesempatan dan waktu yang mereka gunakan untuk memperoleh informasi kesehatan.

Orang tua dengan ekonomi menengah ke atas lebih bersikap permisif dibandingkan dengan orang tua dengan ekonomi menengah kebawah mereka lebih bersikap demokratis. ${ }^{12} \mathrm{Hal}$ diatas menunjukkan bahwa pendapatan keluarga yang memadai akan menunjang perkembangan anak karena orang tua dapat menyediakan semua kebutuhan anak baik yang primer maupun yang sekunder. ${ }^{13}$

\section{b. Gambaran data demografi anak di}

\section{Dusun Kalirandu Bangunjiwo}

\section{Kasihan Bantul Yogyakarta}

Jenis kelamin anak dapat mempengaruhi dalam kesiapan toilet training. Pada kesiapan fisik anak laki- laki cenderung lebih cepat bisa berjalan dan berlari ke kamar mandi dibandingkan dengan anak perempuan. Hal tersebut sesuai dengan penelitian sebelumnya, ${ }^{14}$ bahwa kemampuan motorik kasar anak laki-laki lebih besar dari pada anak perempuan.

Menurut ahli psikologi, 8 pada usia ini anak berada dalam fase anal ditandai dengan berkembangnya kepuasan (kateksis) dan ketidakpuasan (antikateksis) disekitar fungsi eliminasi. Tugas perkembangan yang penting pada fase anal saat anak mencapai usia 2 tahun adalah toilet training agar anak dapat melakukan buang air secara teratur dan benar, sehingga anak menunjukkan kesiapan untuk dilatih toilet training. Menurut ahli, ${ }^{9}$ kontrol usus dan kandung kemih dicapai kirakira setelah anak bisa berjalan yaitu usia 18-24 bulan, sehingga pada usia ini memungkinkan anak untuk dapat mencapai kesiapan toilet training dengan baik.

c. Gambaran pola asuh orang tua di Dusun Kalirandu Bangunjiwo

\section{Kasihan Bantul Yogyakarta}

Hasil penelitian didapatkan gambaran bahwa sebagian besar orang tua menggunakan pola asuh demokratis sebanyak 30 responden $(68,2 \%)$. Pola asuh demokratis merupakan suatu 
bentuk perlakuan orang tua ke anaknya dengan menumbuhkan keyakinan dan kepercayaan diri maupun mendorong tindakan-tindakan untuk membuat keputusan sendiri namun masih dalam pengawasan orang tua.

Pola asuh demokratis cenderung bersikap responsif terhadap kebutuhan anak. pola asuh ini menerapkan suatu keseimbangan antara ketatnya peraturan dengan kebebasan yang menyebabkan anak mendapatkan kebebasan untuk membangun kepercayaan dirinya sendiri. ${ }^{15}$

Pola asuh orang tua dapat dipengaruhi oleh usia orang tua. Orang tua yang usianya muda cenderung lebih bersifat demokratis dan permisif dalam menerapkan pola asuh ke anaknya. Hal ini dikarenakan pasangan orang tua dengan usia muda lebih bisa berdialog dengan baik ke anaknya sehingga hubungan anak dan orang tua seperti seorang sahabat. ${ }^{8}$

Anak dengan pola asuh demokratis cenderung akan menjadi anak yang bersahabat, memiliki rasa ingin tahu yang tinggi, tujuan hidup yang jelas, tanggung jawab tinggi, dan berorientasi pada prestasi yang nantinya akan mendasari anak untuk menentukan kehidupan yang akan datang. ${ }^{16}$ d. Gambaran kesiapan toilet training pada anak usia toddler di Dusun Kalirandu Bangunjiwo kasihan Bantul Yogyakarta

Toilet training adalah suatu proses pengajaran kepada anak untuk mengontrol buang air kecil dan buang air besar secara benar dan teratur, biasanya kontrol buang air kecil terlebih dahulu setelah itu diikuti dengan kontrol buang air besar ${ }^{6}$

Kesiapan toilet training pada anak dipengaruhi oleh beberapa factor diantaranya kesiapan fisik, mental, psikologis, dan orang tua. ${ }^{5}$ Pada toilet training ini merupakan suatu tugas besar pada anak usia balita biasanya terjadi antara usia 18-24 bulan. ${ }^{7}$ Masingmasing anak mempunyai waktu yang berbeda-beda untuk melakukan toilet training. ${ }^{17}$

Menurut salah satu referensi, 5 kesiapan toilet training dipengaruhi oleh kesiapan orang tua. Hal ini sesuai dengan hasil penelitian bahwa usia orang tua paling banyak usia 20-40 tahun sebanyak 36 orang $(81,8 \%)$ yang artinya usia orang tua berpengaruh terhadap kebiasaan toilet training yang benar pada anak. 
2. Analisis Bivariat

a. Hubungan pola asuh orang tua dengan kesiapan toilet training pada anak usia toddler di Dusun

\section{Kalirandu Bangunjiwo kasihan}

\section{Bantul Yogyakarta}

Hasil penelitian ini menunjukkan ada hubungan antara pola asuh orang tua dengan kesiapan toilet training pada anak usia 1-3 tahun di Dusun Kalirandu Bangunjiwo Kasihan Bantul Yogyakarta.

Peran orang tua khususnya ibu sangat dibutuhkan anak dalam toilet training karena sebagian besar anak lebih sering dekat dengan ibunya .${ }^{18}$ Keterlibatan ayah lebih diartikan pada tercapainya keseimbangan antara kedua orang tua dalam memenuhi kebutuhan anak salah satunya yaitu toilet training. ${ }^{19}$

Gaya pengasuhan orang tua biasanya dipengaruhi oleh usia. Pasangan orang tua dengan usia yang lebih muda cenderung bersikap responsif terhadap kebutuhan anak dan bersifat terbuka. ${ }^{7}$ Selain itu, gaya pengasuhan juga biasanya dibawa dari pengalaman yang diterima dalam pengasuhan terdahulu saat mereka masih kecil. Hal ini dapat mempengaruhi tingkat kesiapan anak dalam toilet training dengan cara melatih anak untuk duduk di toilet dan dilakukan secara teratur dan benar saat anak ingin buang air kecil dan buang air besar. ${ }^{20}$

Menurut penelitian terdahulu, ${ }^{21}$ orang tua dalam mengasuh anak perlu memahami kebutuhan yang diperlukan untuk mencapai tingkat perkembangan. Orang tua juga selayaknya sudah mengerti dan faham bahwa anak sejak usia dini mulai memunculkan keterampilan-keterampilan baru, baik keterampilan fisik maupun keterampilan mentalnya.

Dari hasil penelitian didapatkan bahwa pola asuh otoriter cenderung menghasilkan kesiapan toilet training anak dengan kategori cukup sebanyak 9 orang yang dapat menyebabkan anak belum siap secara penuh untuk dilakukan toilet training. Hal ini dibuktikan dengan 22 responden yang menerapkan pola asuh demokratis menghasilkan kesiapan toilet training dengan kategori baik. Hal tersebut sesuai dengan penelitian sebelumnya, bahwa pola asuh orang tua yang overprotektif atau otoriter merupakan faktor yang paling berpengaruh yang menyebabkan anak menjadi tidak mandiri.

Orang tua mempunyai banyak cara dalam memberikan pelatihan toilet training, salah satunya memberikan contoh yang benar dan baik bagi 
anaknya terlebih dahulu sehingga orang tua akan menjadi role model bagi anak. Dengan melihat orang tuanya maka anak akan lebih cepat dan tanggap dalam toilet training. Hal ini sesuai dengan penelitian lain yang menyatakan ada pengaruh modeling media video terhadap peningkatan kemampuan toilet training pada anak retardasi mental. ${ }^{22}$

Kesiapan toilet training dipengaruhi oleh beberapa faktor diantaranya kesiapan fisik, mental, psikologi, dan orang tua. Namun, motivasi orang tua sangat dibutuhkan dalam hal ini. Motivasi orang tua sendiri dipengaruhi oleh faktor instrinsik dan ekstrinsik. Faktor intrinsik yaitu dorongan yang ada pada diri sendiri berupa pengetahuan, sikap, keadaan mental, dan kematangan usia. Sedangkan faktor ekstrinsik yaitu lingkungan, sarana, dan prasarana. $^{23}$

\section{KESIMPULAN}

1. Pola asuh orang tua yang dominan diterapkan kepada anak usia 1-3 tahun di Dusun Kalirandu Bangunjiwo adalah pola asuh demokratis sebanyak 27 orang tua $(61,4 \%)$.

2. Kesiapan toilet training pada anak usia 13 tahun di Dusun Kalirandu Bangunjiwo sebagian besar baik sebesar $32 \operatorname{anak}(72,7 \%)$.
3. Hasil penelitian menunjukkan bahwa ada hubungan antara pola asuh orang tua dengan kesiapan toilet training pada anak usia 1-3 tahun di Dusun Kalirandu Bangunjiwo Kasihan Bantul Yogyakarta.

\section{SARAN}

1. Bagi orang tua

Orang tua diharapkan dapat memberikan pola asuh yang baik terhadap anak sesuai dengan tingkat perkembangan usianya. Selain itu, orang tua juga diharapakan dapat mengevaluasi tingkat perkembagan anak untuk dapat mendeteksi adanya keterlambatan dan tumbuh kembang anak.

2. Bagi ilmu keperawatan

Bagi perawat, khususnya perawat anak dapat dijadikan sebagai bahan informasi dan pendidikan kesehatan ke masyarakat untuk menerapkan pola asuh yang baik terhadap anak sesuai dengan tingkat perkembagan usianya secara optimal.

3. Bagi peneliti lain

Penelitian ini diharapkan dapat mengawali penelitian-penelitian selanjutnya mengenai pola asuh orang tua terhadap perkembangan anak dan hendaknya para peneliti dapat 
menambah variable penelitian diluar penelitian ini.

\section{DAFTAR PUSTAKA}

1. Sugiharti. (2010). Perkembangan anak prasekolah (Golden age).

2. Hidayat, A. (2005). Pengantar ilmu keperawatan anak I. Jakarta: Salemba Medika.

3. Djamaludin, E. (2010). Panduan Pintar Merawat Bayi dan Balita. Jakarta: Wahyu Media.

4. Santrock,J.W. (2007). perkembangan anak. Edisi Ke-11 Jilid 1. Jakarta: Erlangga.

5. Wong. D,L. (2009). Buku Ajar Keperawatan Pediatrike Edisi 6 Volume I. Jakarta: EGC.

6. Hidayat. A. (2008). Pengantar Ilmu Keperawatan Anak Edisi I. Jakarta: Salemba Medika.

7. Nursalam. (2008). Asuban Keperawatan Bayi dan Anake (untuke perawat dan bidan) Edisi 1. Jakarta: Salemba Medika.

8. Hurlock, Elizabeth B. (2010). Perkembangan anak jilid I. Edisi enam. Jakarta: Erlangga.

9. Bokko, D. (2014). Hubungan pola asuh orang tua dengan tingkat kemandirian anak usia pra sekolah di kelurahan pantan kabupaten tana toraja. Dosen Akademi Keperawatan Toraja Kabupaten tanu Toraja Propinsi Sulawesi Selatan.

10. Baker, H. \& Lopez, H. (2010). early childhood stimulation interventions in developing countries: a comprehensive literature review. Diakses 29 November
2013, dari http:/ /ftp.iza.org/dp5282.pdf.

11. Laili, D, K \& Ika, M. (2014). Pola Asuh Orang Tua Mempengaruhi Perkembangan Balita di Posyandu Arjuna RW IV Pos 3 Kelurahan Kemayoran Kecamatan Krembangan Surabaya. Jurna: UNUSA FIK Prodi S1 Keperawatan Surabaya.

12. Amelia, E. (2014). hubungan pola asuh orang tua dengan perkembangan bahasa anak usia 3-5 tahun di PAUD Aisyiyah Nur'aini Ngampilan Yogyakarta. Karya Tulis Ilmiah: Program Studi Ilmu Keperawatan Universitas Mubammadiyah Yogyakarta.

13. Ulumuddin, I. (2014). hubungan pola asuh orang tua dengan perkembangan motorik anak usia 3-5 tahun di PAUD Aisyiyah Nur'aini Ngampilan Yogyakarta. Karya Tulis Ilmiah: Program Studi Ilmu Keperawatan Universitas Muhammadiyah Yogyakarta.

14. Dzatullah, Sutomo. (2014). Perbedaan kemampuan motorik kasar siswa dan siswi kelas v SD negeri tlogoadi desa tlogoadi kecamatan mlati kabupaten sleman.

15. Steinberg. (2011). Adolescence. New York: Mc. Graw Hill.

16. Baumrind, Amelia. (2014). The Influence of Parenting Style on Adolescent competence and subtance use. Journal of early adolescent, 11 (1), 5695.

17. Suririnah. (2010). Perawatan Bayi dan Anak. Jakarta: Gramedia.

18. Supartini, Y. (2006). Buku ajar konsep dasar keperawatan anak. Jakarta: EGC.

19. Batuatas, Risfan. (2012). pengaruh peran ibu terhadap keberhasilan toilet 
training pada anak usia toddler di play group tarbiatush shibiyan mojoanyar mojokerto.

20. Ratne. (2016). Hubungan Pola Asuh Orangtua dengan Keberhasilan Toilet Training Pada Anak Usia Toddler Di Desa Nyatnyono Kecamatan Ungaran Barat Kabupaten Semarang. Skripsi: Program Studi Keperawatan Sekolah Tinggi Imu Kesehatan Ngudi Waluyo Ungaran.

21. Rini, I.D. (2015). Gambaran Pengetahuan Ibu Tentang Perkembangan Bicara dan Bahasa Serta Stimulasinya pada Anak Usia Dini. Diakses November 2013, http://www.google.com/search?outp $\mathrm{ut}=$ search\&sclient $=$ psyab\&q $=$ stimulas $i+$ pada + anak + usia + dini + pdf\&btnG $=$ \#\&psj+1.

22. Faikoh, N. E. (2014). Pengaruh modelling media video terhadap peningkatan kemampuan toilet training pada anak retardasi mental usia 5-7 tahun di SLBN Semarang. http://pmb.stikestelogorejo.ac.id/ejournal/index.php/ilmukeperawatan/a rticle/view/229/254.

23. Ningsih, S, F. (2012). Hubungan Pengetahuan dan Perilaku Ibu dalam Menerapkan Toilet Training dengan Kebiasaan Mengompol Pada Anak Usia Prasekolah di RW 02 Kelurahan Babakan Kota Tangerang. Skripsi. Universitas Islam Negeri Syarif Hidayatullah.

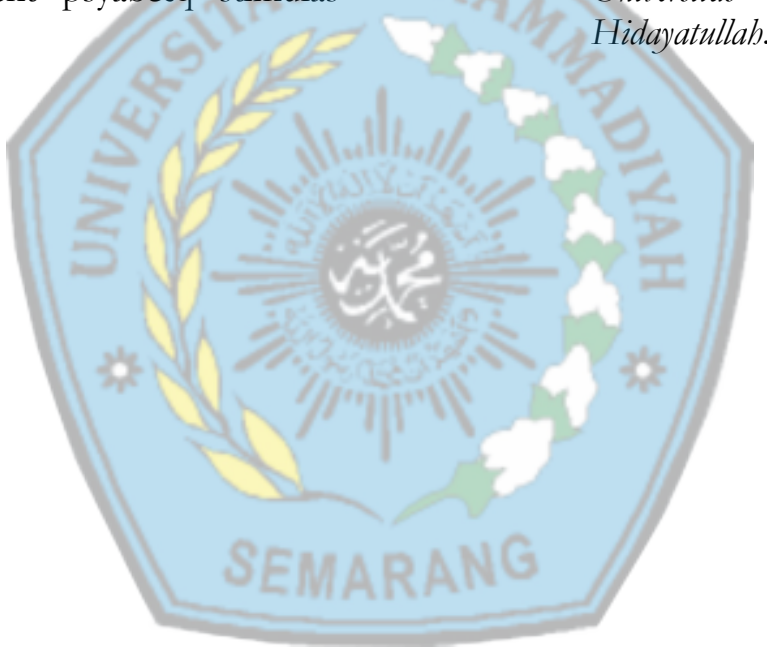

Vol. 1 No.5 Agustus 2018 